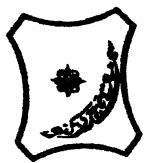

Bayero Journal of Pure and Applied Sciences, 6(1): 12 - 16

Received: December 2012

Accepted: April 2013

ISSN $2006-6996$

\title{
PREVALENCE OF BOVINE FASCIOLOSIS IN MAJOR ABATTIORS OF ADAMAWA STATE, NIGERIA
}

\author{
${ }^{1}$ Ardo, M. B., Aliyara ${ }^{2}$, Y. H. and Lawal ${ }^{3}$, H. \\ ${ }^{1}$ Department of Animal Science and Range Management, Modibbo Adama Univesity of Technology, Yola. \\ ${ }^{2}$ Department of Animal Science Taraba State University , Jalingo \\ ${ }^{3}$ Department of Agricultural Economics \& Extension, Modibbo Adama Univesity of Technology, Yola. \\ Correspondence author: ardofuty@yahoo.co.uk
}

\begin{abstract}
Cross sectional epidemiologic studies of bovine Fasciolosis was conducted in some selected abattoirs of Adamawa state (Yola, Mubi and Numan) using postmortem examination from liver of slaughtered animals.A total of 3,015 slaughtered cattled were examined at post mortem and 657 (21.8\%) liver fluke cases were recorded. The prevalence rate at Yola, Mubi and Numan were $22.08 \%, 22.34 \%$ and $19.92 \%$ respectively. The overall sex-specific prevalence rate was significantly higher $(P<0.05)$ in females $(23.6 \%)$ than in males $(18.2 \%)$. Age specific prevalence rate was higher (23.3\%) in the group that were $49-72$ months. Statistical analysis showed no significant difference in prevalence rate among the age groups: there is no association between infection rate and age. The breed specific prevalence was lowest $(12.32 \%)$ in sokoto gudali and highest (31.2\%) in red bororo. Chi-square analysis indicated that there was strong asssociation between infection and breeds. A significant difference $(P<0.05)$ was observed between the prevalence of fasciolosis that occurred in the dry season (25.98\%) and that of the rainy season $(18.14 \%)$. The result shows strong association $(P<0.05)$ between season, sex, and breeds, of cattle and the disease. It was also observed that bovine fasciolosis is an obstacle to livestock production and development in Adamawa state and Nigeria.
\end{abstract}

Keywords: Prevalence, Bovine, Fasciolosis, Abattoirs, Adamawa state.

\section{INTRODUCTION}

Fasciolosis a parasitic disease of cattle, buffaloes, sheep, goats horses and human of all ages caused by liver flukes (Armour, 1975; Ramajo et al., 2001). Fasciola a trematode belonging to the sub- class Digenea, which is commonly known as liver fluke that infect the biliary ducts (Ramajo et al., 2001). There are two most common species of Fasciola responsible for wide spread morbidity and mortality in ruminants (Soulsby 1992, Urguhuart et al., 1989). These are Fasciola gigantica ( $F$. gigantica) found in the tropics and sub tropics and Fasciola hepatica ( $F$. hepatica) in the temperate zones. Losos (1995) reported that $F$. gigantica predominates in Africa and it is usually transmitted by a snail of the genus Lymnae which get to the definitive or final host following the ingestion of the metacercariae during grazing on vegetation. Tropical Fasciolosis caused by infection with $F$. gigantica is regarded as one of the most important single helminth infections of ruminants in Asia and Africa (Murell, 1994; Harrison et al., 1996; Roberts and Suhardono, 1996; Malone, 1997). Together with major nematode infections, Fasciolosis is a significant constraint on the productivity of domestic ruminants throughout Asia, South-East Asia and Africa and is thus a significant impediment to global food production (Dargie, 1987; Fabiyi, 1987; Murell, 1994). Ogunrinade and Ogunrinade (1980) reported a total liver condemnation rate of $7 \%$ among cattle population of 10 million from slaughter rate of $4 \%$ in Nigeria. In $1986,46.3 \%$ of livers were condemned due to $F$. gigantica in Zimbabwe (Chambers, 1987).
There is a serious paucity of epidemiologic data on the disease in Adamawa state as no comprehensive work has been done. Adamawa, located in the semi-arid zone of north-eastern Nigeria, is the third largest cattle producing state in the country, and a major supplier of cattle and beef to most parts of Nigeria. Preliminary surveys suggest wide-spread prevalence of the zoonotic infection in cattle populations, with grave public health risk. This problem is compounded by the seasonal migration of cattle from the northern parts of the states to Cameroun Republic.

\section{MATERIALS AND METHODS \\ Study Area}

The study was conducted in Adamawa State, Nigeria located on latitudes $09^{\circ} 14^{\prime} \mathrm{N}$ and Longitude $12^{\circ} 8^{\prime} \mathrm{E}$. The State has a tropical climate, marked with two distinct seasons- wet season (April-September) and dry season (October to March). It has an average annual rainfall of $759 \mathrm{~mm}$ with wettest months being July-September. The drier months of the year are January-March when relative humidity drops to $13 \%$. Mubi, Ngurore, Ganye, Song, Yola, Fufore, Lafia and Konkol are the major cattle markets where butchers purchase their animals for slaughter at Yola, Mubi and Numan abattoirs.

Adamawa State has a cattle population of over four (4) million (Adamawa, ADP, 2004) and cattle rearing is a major occupation of Adamawa people. The land mass of each of the 21 Local Government Areas of the State is covered by 'Fadama' which predispose cattle to infestation particularly during the dry season. 


\section{Study Population}

The three abattoirs (Yola, Mubi and Numan) used in this study have an average slaughter of 30, 20 and 10 cattle per day respectively. Two visits per week were made to Yola abattoir and once a week for Mubi and Numan abattoirs. Fifteen (15) animals were sampled at Yola abattoir; ten (10) animals were examined in Mubi, while all animals slaughtered were examined at Numan abattoir. Thus, for every week thirty (30) animals were examined at Yola giving a total of 40 animals screened out of the estimated total slaughter of $75(60 \%)$ during the visit days.

Weekly visit to abattoirs were made for one calendar year. Thus, a total of $3,000(60 \times 50)$ slaughtered cattle were examined out of 5,000 estimated total slaughter during the visit days.

Adamawa Gudali, White Fulani, Red Bororo and Sokoto Gudali are the breeds slaughtered at Yola, Mubi and Numan abattoirs

\section{Age Estimation}

The age of cattle was estimated by observing the front permanent teeth either before slaughtering or after slaughtering. The eruption of front teeth which occurs as follows as a guide $1^{\text {st }}$ pair $1.5-2$ years; $2^{\text {nd }}$ pair 2-2.5 years; $3^{\text {rd }}$ pair $3-3.5$ years; $4^{\text {th }}$ pair 4 years and above 4 years wearing of permanent incisors (Carlson, 1974).

Procedure for post mortem inspection of the liver

Post mortem inspection was carried out according to the method described by Thornton's and Gracey (1981). Meat inspection at Yola, Mubi and Numan abattoirs was carried out by officials of Ministry of Livestock and nomadic resettlement. The team comprises of a Veterinarian with official meat inspectors. Liver examination was carried concurrently during meat inspection of bovine carcasses and organs

\section{Statistical Analysis}

The data were analysed and presented using descriptive statistics such as means and tables. Chisquare was used to establish association between fluke infection and sex, breed or season. Student ttest and ANOVA Was used to determine the significance of difference in mean distribution of the flukes between the variables.

\section{RESULTS}

Liver flukes (Fasciola) were detected in 657 (21.79\%) of the 3,015 slaughter cattle examined over the one year study period. The prevalence rates at Yola, Mubi and Numan abattoirs were $22.08 \%, 22.34 \%$ and $19.92 \%$ respectively (Table 1 ). The prevalence was the same $22 \%$ for Yola and Mubi while Numan had the lowest percentage prevalence (19.92\%).

With respect to seasonal occurrence, out of a total of 1,405 slaughter cattle examined at the three abattoirs in the state during the dry season (October to March), Liver flukes were detected in 365 (26\%) and out of the 1,610 examined during the wet season $292(18 \%)$ were positive for Fasciolosis (Table 2). There was a significant difference $(p<0.05)$ in prevalence rates between the seasons. All the three abattoirs in the state showed a similar seasonal trend.

Comparison a rate of infestation with respect to sex revealed that, one hundred and eighty five (185) of the 657 Fasciola positive cattle (28.2\%) were males and 472 of the positive $(71.8 \%)$ were females (Table $3)$. For the State, the overall sex-specific prevalence rate was $18.2 \%$ for males and $23.6 \%$ for females. Liver fluke infection is significantly higher in females than in males $\left(X^{2}=11.9, P<0.05\right)$, (Table 3 ).

Among all the Fasciola positive cattle a significant variation with respect to age was observed. Highest numbers were in those cattle aged above 72 months and the lowest in the age bracket of 0-24 months (Table 4). Age specific prevalence rate was highest $(23.3 \%)$ in the groups that were $49-72$ months (Table 4). Chi-square statistical analysis showed no significant difference $(P>0.05)$ in prevalence rate among the age groups; there was no association between infection rate and age $\left(x^{2}=2.39, p<0.05\right)$ (Table 4).

The distribution of Fasciolosis amongst breeds of cattle slaughtered and examined were as shown in Table 5. The breed specific prevalence rate was lowest $61(12.32 \%)$ in Sokoto Gudali and highest 325 (31.34\%) in Red Bororo. Prevalence rate in Adamawa Gudali was $158(19.9 \%)$ and $113(16.4 \%)$ in White Fulani (Table 5). Chi-square statistical analysis indicated that there was significant difference $(P<0.005)$ in prevalence between breeds (Tables 5$)$. There was an association between infection rate and breed of cattle.

Table 1: Prevalence of Fasciolosis in cattle slaughtered at Adamawa state abattoirs.

\begin{tabular}{lcc}
\hline Location & Number examined & Number (\%) positive \\
\hline Yola & 1,490 & $329(22.08)$ \\
Mubi & 998 & $223(22.34)$ \\
Numan & 527 & $105(19.92)$ \\
Total & $\mathbf{3 , 0 1 5}$ & $\mathbf{6 5 7}(\mathbf{2 1 . 7 9 )}$ \\
\hline
\end{tabular}

Table 2: Seasonal prevalence of Fasciolosis in cattle slaughtered at some selected abattoirs in Adamawa State Nigeria

\begin{tabular}{lll}
\hline Season & No examined & No. (\%) positive \\
\hline Dry(Oct-March) & 1405 & $365(25.98)$ \\
Wet(April-Sept) & 1610 & $292(18.14)$ \\
Total (Overall) & $\mathbf{3 0 1 5}$ & $\mathbf{6 5 7}(\mathbf{2 1 . 7 9 )}$ \\
\hline $\mathrm{X}^{2}=10.4, \mathrm{P}<0.05$ & &
\end{tabular}


Table 3: Prevalence of Fasciolosis in cattle slaughtered among sexes at some selected abattoirs in Adamawa state, Nigeria

\begin{tabular}{llllll}
\hline Location & $\begin{array}{l}\text { No. } \\
\text { Examined }\end{array}$ & $\begin{array}{l}\text { No. (\%) } \\
\text { positive }\end{array}$ & $\begin{array}{l}\text { No. } \\
\text { examined }\end{array}$ & $\begin{array}{l}\text { No. (\%) } \\
\text { positive }\end{array}$ & \\
\hline Yola & 509 & $100(19.65)$ & 981 & $229(23.34)$ & $329(22.08)$ \\
Mubi & 331 & $62(18.73)$ & 667 & $161(24.14)$ & $223(22.34)$ \\
Numan & 117 & $23(12.99)$ & 350 & $82(23.43)$ & $105(19.92)$ \\
Total & $\mathbf{1 , 0 1 7}$ & $\mathbf{1 8 5 ( 1 8 . 1 9 )}$ & $\mathbf{1 , 9 9 8}$ & $\mathbf{4 7 2 ( 2 3 . 6 2 )}$ & $\mathbf{6 5 7}(\mathbf{2 1 . 7 9 )}$ \\
\hline
\end{tabular}

$\mathrm{X}^{2}=11.9, \mathrm{P}<0.05$

Table 4: Age specific prevalence of Fasciolosis in cattle slaughtered in Adamawa State, Nigeria.

\begin{tabular}{lcc}
\hline Age (months) & Number examined & Number (\%) positive \\
\hline $0-24$ & 215 & $43(20)$ \\
$25-48$ & 420 & $85(20.2)$ \\
$49-72$ & 933 & $217(23.3)$ \\
$>72$ & 1447 & $312(21.6)$ \\
Total & 3,015 & $625(21.79)$ \\
\hline
\end{tabular}

$\mathrm{X}^{2}=2.39 \mathrm{P}<0.05$

Table 5: Overall breed-specific prevalence of Fasciolosis in cattle slaughtered in Adamawa State, Nigeria

\begin{tabular}{lcc}
\hline Breed & Number examined & Number (\%) positive \\
\hline Red Bororo & 1,037 & $325(31.34)$ \\
Adamawa Gudali & 794 & $158(19.90)$ \\
White Fulani & 689 & $113(16.40)$ \\
Sokoto Gudali & 495 & $61(12.32)$ \\
Total & 3015 & $657(21.79)$ \\
\hline
\end{tabular}

$\mathrm{X}^{2}$ at $3 \mathrm{df}=7.815, \mathrm{P}<0.05$

\section{DISCUSSION}

This study which covered Adamawa state, employed (post-mortem examination of liver but did not use abattoir records and carpological method (faecal analysis) revealed an overall prevalence of $21.8 \%$ liver fluke infection which is lower than the $31.7 \%$ reported by Babalola and Schillhorn van Veen. (1976) in Bauchi state, and Ikeme and Obioha (1973) ,reported 26\% in trade cattle in south eastern Nigeria. Most of the fluke infected cattle in the southern abattoirs, originate from the northern parts of the country (Uzoukwu and Ikeme, 1978).Nwosu and Strivastava (1993) reported a prevalence of $42.2 \% \quad F$. gigantica eggs in gall bladder of cattle slaughtered in Maiduguri. Mungube et al. (2006) also reported an overall prevalence of $26 \%$ in bovine slaughtered in the semi-arid coastal Kenya The prevalence rate obtained in this study is also lower than the $36.5 \%$ reported in Uganda (Magona et al., 1999) and $31.7 \%$ reported in Zimbabwe (Pfukenyi and Makaratirwa, 2004), but similar to the $21 \%$ reported in Ethiopia (Tegene, 1994). This difference may possibly be because of environmental factors. In the United States of America Knapp et al. (1992) reported a prevalence rate of $17.24 \%$. The time of exposure during grazing to detection of mature fluke in infected animal takes about 70-90 days (Reichel; 2002). This means that initial exposure occurs in the rainy season and high prevalence of adult infection was recorded during the dry season. The prevalence rates of $25.98 \%$ in dry season (October to March) and $18.14 \%$ in wet season (April to September) recorded in this study indicates strong association between infection prevalence and the seasons. In Nigeria the pattern of distribution of Fasciolosis followed areas of high rainfall, snailinfested areas and areas of high animal density (Fabiyi and Adeleye, 1982). The higher prevalence of the disease in dry season in this study agrees generally with workers who noted that prevalence of bovine Fasciolosis was higher in dry season (January to April), with the peak occurring in March (Ademola, 2003). Babalola (1975) reported a prevalence rate of $31.7 \%$ in dry season with peak of $40.7 \%$ in October in Northern Nigeria. Although an increasing trend was observed with the advancement of the dry season, relatively high prevalence rates were recorded throughout the study period. Phiri et al. (2005) in their studies of seasonal pattern of bovine Fasciolosis in the Kafue and Zambezi catchment areas of Zambia using coproscopic examination and liver inspection reported more cattle were found positive during the post-rainy season than in any other season. However, this present study that showed Fasciolosis to occur throughout the year agree with the findings of Vassilev and Jooste (1991) in Zimbabwe. Fasciola can live for more than one year in cattle, producing eggs continiously this complicates the determination of the major risk periods (Range-Ruiz et al., 1999). Makundi (2001) in Tanzania also reported F. gigantica in cattle being high during the dry season and low during the rainy season while the peak transmission of trematodes as occurring at the end of the rainy season. 
The findings in this study is contrary to the observation of Mzembe and Chaudhry (1981) who reported the prevalence rate of $F$. gigantica to be significantly higher during the wet season than dry season.

The distribution of the disease according to sex has shown that female cattle were more significantly $(P<0.05)$ affected than the males. The results in the present study are in accord with the findings of Phiri et al. (2005) in Zambia; Keyyu et al. (2005) in Tanzania and Vassilev (1999) in Zimbabwe. Despite male and female cattle grazing together in the same pasture, female cattle had a higher infection rate than male cattle, suggesting that difference in susceptibility between sexes may exist (Phiri et al., 2005). Another possible explanation to the variation could be due to the fact that the females stay longer in the herd (for purpose of reproduction and breeding) and hence the higher burden of this disease. (Schillhorn Van Veen et al., 1980).

Age distribution of bovine Fasciolosis at slaughter revealed that those greater than 72 months had highest number of cases than those in 49-72 months age bracket. However, chi-square statistical analysis for significance showed there is no association between infection rate and age. Yilma and Mesftin (2000) in Ethiopia reported the existence of significant difference and inverse correlation in infection prevalence among different age groups. The present result however, agreed with the findings of earlier workers (Ogunrinade and Ogunrinade 1980; Fabiyi and Adeleye1982)

\section{REFERENCES}

Adamawa Agricultural Development Projects (2004): Third Quarterly Reports (July to September).

Ademola, I. (2003): Meterorological changes and their influence on the epidemiology of fasciolosis in food animals slaugthered in Oyo state. Nigerian Veterinary Journal 24 (3):35-38.

Armour, J. (1975): The Epidemiology and Control of Bovine Fascioliasis, Veterinary Record. 96:198201.

Babalola, D.A. (1975): Liver disease of slaughtered cattle at Bauchi, North-eastern State, Nigeria. Bulletin of Animal Health and Production in Africa 23:419-421.

Babalola, D. A. and Schillhorn Van Veen,T. W.(1976): Incidence of Fascioliasis in cattle slaughtered in Bauchi (Nigeria). Tropical Animal Health and Production 8:234-247

Carlson, J. (1974): Raising Healthy Cattle under Primitive Condition, Revised $2^{\text {nd }}$ ed. U.S.A Box 3300 eattle, Washington 98133, pp 39-40.

Chambers, P.G. (1987): Carcass and offal condemnations at meat inspection in Zimbabwe. Zimbabwean Veterinary Journal 18:11-18.

Dargie, J.D. (1987): The impact of production and mechanism of pathogenesis of trematodes infections in cattle and sheep. International Journal for Parasitology 17: 453-463.
Breed specific distribution of the disease in cattle showed that the Red Bororo has higher prevalence rate than the other two breeds. This may be the fact that the Red Bororo breed generally grazes in areas like Lake-borders, low lying marshy areas, streams, slow flowing rivers and valleys of River Benue all year round (Fabiyi et al., 1980; Olusi, 1996). It may as well be due to the fact that the Red Bororo slaughtered were generally older and had stayed in the herd longer than the other breeds slaughtered. Wamae et al. (1998) have clearly indicated breed difference in the production losses associated with Fasciolosis in yearling Friesian and Boran cattle in Kenya.

\section{CONCLUSION}

The findings in this study confirm that bovine Fasciolosis is an endemic disease in the study area and is an indication of the existence of favourable bionomic and ecological conditions for the survival, multiplication and spread of intermediate snail host and the parasite in that environment. The occurrence of slow flowing rivers, streams, low-lying marshy areas around River Benue and its tributaries in the grazing circuit of cattle, high livestock density and seasonal migration increase the risk of acquiring the infection. However the prevalence study did not include coprological methods. There is a need not only to intensify but improve the control methods of Fasciolosis in livestock production in Adamawa in order to minimize the economic losses and also to educate the public so that they are aware of its importance.

Fabiyi, J. P. and Adeleye, G. A. (1982): Bovine Fascioliasis on the Jos plateau, Northern Nigeria with particular reference to economic importance. Bulletin of Animal Health and Production in Africa, 30: 41-43.

Fabiyi, J. P., Okon, E. D. and Ogunsisi, R. A. (1980): Survey and Feasibility Studies of Fascioliasis and Parasitic Gastro-enteritis Complex in Ruminants in Nigeria, a Report of the Livestock Department.

Fabiyi, J.P. (1987): Production Losses and Control of Helminthes in Ruminants of Tropical Regions. International Journal for Parasitology 17: 435 442.

Ikeme, M.M. and Obioha, F.C. (1973): Fasciola gigantica Infections in Trade Cattle in Eastern Nigeria. Bulletin of Epizootic Disease of Africa 21:259-264.

Keyyu, J.D., Moniad, J., Kyvsgaard, N.C. and Kassukil, A.A. (2005): Epidemiology of Fasciola gigantica and Amphistomes in cattle in traditional smallscale dairy and large-scale dairy farms in the Southern highlands of Tanzania. Tropical Animal Helath and Production 37: 303-314.

Knapp, S.E., Dunkel, A.M., Han, K and Zimmerman, L.A. (1992): Epizootiology of fasciolosis in Montana. Veterinary. Parasitology, 42: 241246. 
Losos, G. J. (1995): Infectious Tropical Disease of Domestic Animals, $1^{\text {st }}$ ed., Longman Scientific and Technical, New York, Pp 851-894.

Magona, J.W., Olaho-Mukani,W., Musisi, G. and Walubemgo, J. (1999): Bovine fasciolosis infection surrvey for Uganda. Bulletin of Animal Health and Production in Africa 47:9-14.

Makundi,A.E. (2001): Epidemiology and Control of bovine fasciolosis and schistosomiasis in Tanzania Ph.D thesis. Sakoine University of Agriculture, Magogora Tanzania, p.57 ( Unpublished)

Malone, J.B. (1997): The landscape epidemiology of fascioliasis: geographic determinants of disease risk. In: Boray, J.C. (ed) Immunology, Pathophysiology and control of Fascioliasis. Round Table Conference at the VIII $^{\text {th }}$ International Congress of Parasitology, Izmir, Turkey. Merck AgVet, Rahway, New Jersey, pp65-81.

Mungube, E. O., Bauni, S. M., Tenhagen, B. A., Wamae, L. W., Nginyi, J. M. and Mugambi, J. M. (2006): The Prevalence and Economic Significance of Fasciola gigantica and Stilesia hepatica in Slaughtered Animals in Semi-Arid Coastal Kenya, Tropical Animal Health Production 38:475-483

Murrell, K.D. (1994): Dr. Stoll's Wormy World revisited: the neglected animal diseases. Journal of Parasitology 80: 173-188.

Mzembe, S.A.T and Chaudhry,M.A. (1981): The epidemiology of Fasciolosis in Malawi Part II. Epidemiology in the definitive host. Tropical Animal Health and Production, 13:27-33.

Nwosu, C.O and Srivastava, G.C. (1993): Liver flukes infection in Borno State Nigeria. Veterinary Quarterly 15:182-183.

Ogunrinade, A. F. and Ogunrinade, B. I. (1980): Economic Importance of Bovine Fascioliasis in Nigeria, Tropical Animal Health and Production, 12: 155-166.

Olusi, T. A. (1996): The prevalence of liver helminth parasites of ruminants in Maiduguri, Borno states, Nigeria. Bulletin of Animal Health and Production in Africa 44: 151-154.

Pfukenyi, D and Mukaratirwa, S. (2004): A retrospective study of the prevalence and seasonal variation of $F$. gigantica in cattle slaughtered in the major abbatoirs of Zimbabwe between 1990 and 1999. Ondersteeport Journal of Veterinary Research, 71 (3): 181-187.

Phiri, A. M., Phiri, I. K., Sikasunge, C. S. and Monrad, J. (2005): Prevalence of Fasciolosis in Zambia Cattle observed at Selected Abattoirs with Emphasis on Age, Sex and Origin, Journal of Veterinary Medicine Series, 52 (9): 414-416.

Phiri, A.M., Phiri, I.K., Siziya, S., Sikasunge, C.S., Chembensofu, M. and Monrad, J. (2001): Seasonal pattern of bovine fascioliasis in the Kafue and Zambezi catchments areas of Zambia. Veterinary Parasitology, 134: 82-92.

Ramajo, V., Oleaga, A., Casanueva, P., Hillyer, G. V. and Muro, A. (2001): Vaccination of Sheep against Fasciola hepatica with Homologous Fatty Acid binding Proteins, Veterinary Parasitology, 97 (1): 35-46.

Ranget-Ruiz, I.J., Marquez-Izquierdo, R.., and BravoNoguira, G. (1999): Bovine fasciolosis in Tabasco. Mexico Veterinary Parasitology, 81: 119-127.

Reichel, M. P. (2002): Performance Characteristics of an Enzyme Linked Immuno Sorbent Assay for the Detection of Liver Flukes Infection in Sheep and Cattle. Veterinary Parasitolog, 107:65-72.

Roberts, J.A. and Suhardono, A. (1996): Approaches to the control of fascioliasis in ruminants. International Journal for Parasitology, 20: 971-981.

Schillhorn Van Veen, T.W., Folaranmi, D.O.B., Usman, S. and Ishaya, T. (1980): Incidence of liver fluke infections (Fasciola gigantica and Dicrocoelium hospes) in ruminants in northern Nigeria. Tropical Animal Health and Production 12: 97-104.

Soulsby, E. J. W. (1982): Helminths, Arthropods and Protozoa of Domesticated Animals, $7^{\text {th }}$ Ed., Lea and Febiger, Philadelphia, Bailliere and Tindall, London, Pp 221-258.

Tegene, N. (1994): Bovine fasciolosis infection survey in Ethiopia. Bulletin of Animal Health and Production in Africa, 42:199-201.

Thornton's H and Gracey, J. F. (1981): Thornton's Meat Hygiene. $7^{\text {th }}$ Ed., Sassel Ltd, London, Pp 120-128.

Uzoukwu, M and Ikeme, M. M. (1978): Herd changes in natural Fasciola gigantica infection of the Fulani zebu. Bulletin of Animal Health and Production in Africa 126:161-167

Urquahart, G. M., Armour, J., Dunn, A. M. and Jennings, F. W. C (1989): Veterinary Parasitology, Longman, England, Pp 286.

Vassilev, G.D. (1999): Prevalence of internal parasite infection of cattle in the communal farming areas of Mashona Land East Priovince, Zimbabbwe. Zimbabawe Veterinary Journal 30: 1-17.

Vassilev, G.D. and Jooste, R. (1991): Production losses and control of fascioliasis in cattle in Zimbabwe. Zimbabwe Veterinary Journal, 22: 45-56.

Wamae, L.W., Hammond, J.A., Harrison, L.S and Onynago-Abuje, J.A. (1998): Comparison of production losses caused by chronic Fasciola gigantica infection in yearling Friesian and Boran cattle. Tropical Animal Health and Production, 30: 23-30.

Waruiru, R.M., Kyvsgaard, N.C., Thamsborg, S.M., Nansen, P.,Bogh, H.O., Munyua,W.K. and Gathuma, J.M. (2000): The prevelence and intensity of helminths and coccidial infections in dairy cattle in central Kenya. Veterinary Research Communications, 24; 103-127.

Yilam, J.M. and Mesfin, A. (2000): Dry season bovine fascioliasis in Northwestern part of Ethiopia. Rev. Med. Vet., 151 (6):493-500. 